\title{
NOTE
}

\section{Life cycle of the sea lamprey Petromyzon marinus: duration of and growth in the marine life stage}

\author{
Sergio Silva ${ }^{1,2, *}$, María J. Servia ${ }^{3}$, Rufino Vieira-Lanero ${ }^{2}$, Sandra Barca ${ }^{1,2}$, \\ Fernando Cobo ${ }^{1,2}$
}

\author{
${ }^{1}$ Universidad de Santiago de Compostela, Departamento de Zoología y Antropología Física, Campus Vida, \\ 15782 Santiago de Compostela, Spain \\ ${ }^{2}$ Estación de Hidrobioloxía 'Encoro do Con', Castroagudín, 36617 Vilagarcía de Arousa, Pontevedra, Spain \\ ${ }^{3}$ Universidad de A Coruña, Departamento de Biología Animal, Biología Vegetal y Ecología, Facultad de Ciencias, Campus da \\ Zapateira, 15008 A Coruña, Spain
}

\begin{abstract}
Little is known about the marine life-history phase of the anadromous sea lamprey Petromyzon marinus. The most widely accepted hypothesis suggests a hematophagous feeding phase of $2.5 \mathrm{yr}$. We captured and tagged (individually numbered T-bar anchor tags) 408 postmetamorphic sea lampreys during the onset of the hematophagous feeding phase in the River Ulla and its estuary (NW Spain). One marked sea lamprey was recaptured during its spawning migration (total length: $895 \mathrm{~mm}$, weight: $1218 \mathrm{~g}$ ). This individual had been marked 13.5 mo before recapture, and had measured $218 \mathrm{~mm}$ and $20 \mathrm{~g}$. Our results suggest that at least a portion of the sea lamprey population can reach adult size in $1 \mathrm{yr}$ of hematophagous feeding. This further suggests a period between completion of metamorphosis and reproduction of $1.5 \mathrm{yr}$ (18 to $20 \mathrm{mo}$ )
\end{abstract}

KEY WORDS: Growth $\cdot$ Adult $\cdot$ Feeding $\cdot$ Anadromous $\cdot$ Hematophagous $\cdot$ Estuary

\section{INTRODUCTION}

The sea lamprey Petromyzon marinus L., 1758 is an anadromous species that, after several years in freshwater habitats as larvae (Beamish \& Potter 1975, Hardisty 1979, Quintella et al. 2003, Taverny et al. 2005), undergoes metamorphosis that allows young postmetamorphic lampreys to migrate to the sea and begin hematophagous feeding (Youson 1980). In the River Ulla (NW Spain), metamorphosis is completed between October and November, and downstream migration occurs between October and May (Silva et al. 2013). After an unknown time at sea, individuals return to spawning areas in the river to reproduce. Upstream migration in the River Ulla occurs between December and May, and spawning occurs between May and July (Silva et al. 2013), which is similar to the timing of these events in Portuguese rivers (Quintella et al. 2004).
At present, only the freshwater part of the biological cycle of the sea lamprey is partially known and, as is often the case with diadromous fish species, knowledge of biology and distribution during the marine portion of the life cycle is practically nonexistent (OSPAR 2009). The overall picture of the distribution, growth and duration of the marine stage has been inferred from ca. 100 specimens from sporadic and isolated captures (Beamish 1980, Halliday 1991). Based on data obtained from these specimens, Beamish (1980) proposed a hematophagous feeding period of 2 to $2.5 \mathrm{yr}$, whereas Halliday (1991) suggested the possibility of a reduced feeding period (1.5 yr). Previously, using interspecific comparisons, Hardisty \& Potter (1971) proposed that all the large anadromous lamprey species, including sea lamprey, have a hematophagous feeding period of at least $2.5 \mathrm{yr}$. 
The duration of the hematophagous feeding stage has been studied extensively in landlocked populations of sea lamprey in the Great Lakes, and the general conclusion is that less than $1 \mathrm{yr}$ of hematophagous feeding is needed to reach adult size. In these populations, the period between completion of metamorphosis and reproduction is approx. $18 \mathrm{mo}$, but adults are about half the size of anadromous individuals (Applegate 1950, Farmer et al. 1977, Farmer 1980, Johnson \& Anderson 1980, Bergstedt \& Swink 1995).

Age determination and growth studies are crucial to fisheries management and conservation (Quintella et al. 2003). In the case of sea lamprey, there are intensive fisheries in Spain, France and Portugal (Beaulaton et al. 2008, Quintella et al. 2009, Cobo et al. 2010). Thus, the lack of information on the duration of the marine life stage makes this work particularly important. In sea lampreys, statoliths (similar to bony fish otholiths) can be used to estimate the age of lampreys in the larval phase (Volk 1986, Beamish \& Medland 1988, Barker et al. 1997, Morkert et al. 1998, Griffiths et al. 2001, Quintella et al. 2003), but their use for the estimation of age in the marine phase has been unsuccessful (Taverny et al. 2005).

In the present study, we captured, measured and tagged numerous postmetamorphic sea lampreys in the River Ulla during downstream migration and residence in the estuary, which constitute the first months of the hematophagous feeding phase (Silva et al. 2013). This river supports an important commercial fishery of the species, which allowed us to obtain the first recapture of a tagged sea lamprey.

\section{MATERIALS AND METHODS}

Study area. The study area is located in the River Ulla and its estuary (total length $132 \mathrm{~km}, 2803 \mathrm{~km}^{2}$ ), and in the saline estuary Ría de Arousa $\left(230 \mathrm{~km}^{2}\right)$, through which the river drains into the Atlantic Ocean (Galicia, NW Spain).

Individuals were collected at 4 locations, 3 in the estuary (E1, UTM: 29T 528080E 4729817N; E2, UTM: 29T 522247E 4723949N; E3, UTM: 29T 518953E $4716224 \mathrm{~N}$ ) and one in the river (R1, UTM: 29T 543849E 4732719N), approx. $40 \mathrm{~km}$ from the mouth (Fig. 1). For simplicity, sampling locations in the estuary and ría are considered as one locality, and we will refer to them as belonging to the estuary.

Fieldwork. At Sites R1, E2 and E3 we captured and tagged a total of 408 postmetamorphic lampreys between January and May 2011. Individually numbered T-bar anchor tags (FF-94, Floy Tag) were used.

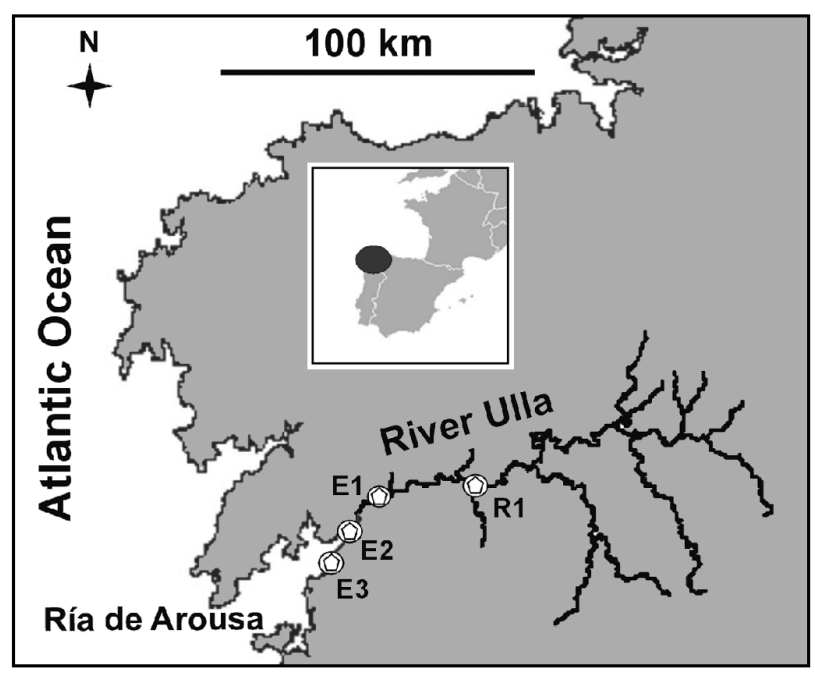

Fig. 1. Location of River Ulla (R) and estuary (E) sampling sites

$\mathrm{R} 1$ is a fixed trap located at the village of Ximonde (Caballero et al. 2006), where 185 postmetamorphic individuals were tagged in April and May 2011. Sampling in the estuary (Sites E2 and E3) was conducted between January and April 2011. At these locations, all postmetamorphic lampreys were captured feeding on the amphidromous golden grey mullet Liza aurata (Risso, 1810) (Fig. 2), as mullet form large schools near the coast. Five sea lamprey were captured in January, 133 in February, 77 in March and 13 in April 2011. Golden grey mullet were captured using hand, seine and gill nets (see Silva et al. 2013). Captured mullet presented fresh and pierced wounds, indicating the existence of feeding and not simply attachment. At Site E1, the River Ulla supports a commercial fishery of sea lamprey.

For all captured sea lampreys, total length (TL; $\pm 1 \mathrm{~mm}$ ) and weight ( $\mathrm{W}_{i} \pm 1 \mathrm{~g}$ ) were recorded. Sampling was conducted on a weekly basis except at R1, where sea lampreys were captured daily.

Data analysis. Specific growth rates $(G)$ for the recaptured lamprey were calculated as: $G_{\mathrm{W}}=$

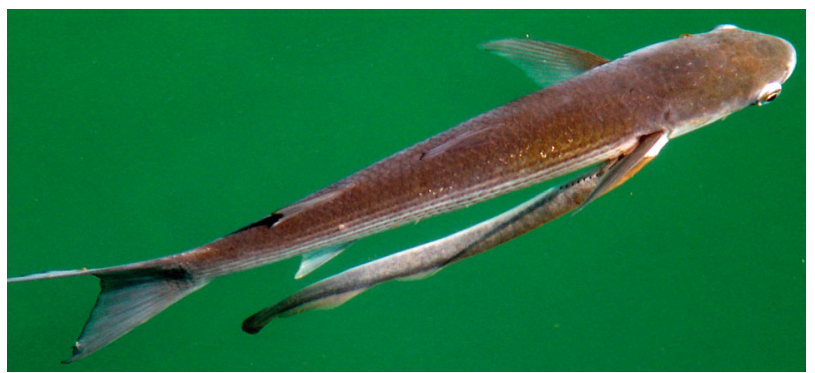

Fig. 2. Postmetamorphic Petromyzon marinus attached to Liza aurata at River Ulla estuary 
$\left\{\left[\ln \left(\mathrm{W}_{2}\right)-\ln \left(\mathrm{W}_{1}\right)\right] / \Delta t\right\} 100$ and $G_{\mathrm{TL}}=\left\{\left[\ln \left(\mathrm{TL}_{2}\right)-\right.\right.$ $\left.\left.\ln \left(\mathrm{TL}_{1}\right)\right] / \Delta t\right\} 100$ (Ricker 1975, 1979), where $\mathrm{W}_{1}$ and $\mathrm{W}_{2}$ and $\mathrm{TL}_{1}$ and $\mathrm{TL}_{2}$ were recorded at the time of tagging and recapture, respectively, and $\Delta t$ is the time period $(\mathrm{d})$.

\section{RESULTS}

On 26 March 2012, we recaptured one tagged sea lamprey (TL: $895 \mathrm{~mm}, \mathrm{~W}: 1218 \mathrm{~g}$ ) at E1 during its upstream migration. This individual had been tagged in the estuary on 1 February 2011 and measured $218 \mathrm{~mm}$ and $20 \mathrm{~g}$, which indicates an increase of $311 \%$ in TL and $5990 \%$ in W in 13.5 mo. This results in a $G_{\mathrm{TL}}$ of $0.340 \% \mathrm{~d}^{-1}$ and a $G_{\mathrm{W}}$ of $0.988 \% \mathrm{~d}^{-1}$. This individual was recaptured 4 mo after the start of the upstream migration period in the River Ulla (December to May), and it was not feeding when it was recaptured.

\section{DISCUSSION}

The size of this lamprey at the time of tagging was close to the size of the postmetamorphic individuals captured during the downstream migration in the River Ulla (Silva et al. 2013), most of which were not feeding (Silva et al. 2013). Assuming the growth rate observed for the recaptured lamprey and the difference in size between this individual and the postmetamorphics captured before the start of feeding, its size at the time of tagging (1 February 2011) would have required a previous feeding period of approx. 1 to 2 mo. Moreover, the spawning migration period in the area began 4 mo prior to recapture. During this migration, and probably 1 to 2 mo earlier, individuals do not feed (Beamish 1980, Johnson \& Anderson 1980), so this sea lamprey may have been fasting for 1 to 4 mo before recapture. After consideration of this information, we estimated that the hematophagous feeding period for this individual is 10.5 to 14.5 mo. Indeed, during this migration lampreys decrease, both in $\mathrm{W}$ and $\mathrm{TL}$, by roughly $5.7 \%$ (Beamish 1980), suggesting that this individual may have reached a larger size during that short time and that the growth rate is probably underestimated.

Given that the metamorphosis in this region ends in October-November, while spawning occurs between May and July (Silva et al. 2013), our results suggest a period between completion of metamorphosis and reproduction of 18 to 20 mo.

Our data suggest that the duration of hematophagous feeding is shorter than hypothesized by
Hardisty \& Potter (1971) and Beamish (1980), although in both cases, the authors indicated that 23 to 28 mo of feeding was weakly supported by their data. Hardisty \& Potter (1971) used comparisons among lamprey species to propose that all the large anadromous lamprey species, which include sea lamprey (excepting the Great Lakes), may have a hematophagous feeding period of at least $2.5 \mathrm{yr}$. Beamish (1980) used scattered information of a few individuals captured in the ocean, and referred also to the work of Farmer et al. (1977), who studied growth of landlocked lampreys of the Great Lakes in the laboratory, which exhibited lower growth rates and sizes than anadromous lampreys (Applegate 1950, Johnson \& Anderson 1980). Halliday (1991) discussed the previous hypothesis using sea captures off the coast of Canada, and suggested a shorter feeding period of $\sim 1.5$ yr. Halliday noted that acceptance of this hypothesis of $1.5 \mathrm{yr}$ of hematophagous feeding requires that individuals captured in early summer, which range in TL from 12 to $65 \mathrm{~cm}$, be considered as from the same cohort. Size variation within a cohort can be explained by individual differences in the onset of feeding. Some young postmetamorphics migrate downstream in late autumn and begin feeding on fish, while others stay in the river and overwinter without feeding, and migrate to the estuary to begin feeding the following spring (Beamish \& Potter 1975, Potter \& Beamish 1977). Similarly, in the River Ulla, postmetamorphic individuals migrate to the estuary anywhere from 0 to 6-7 mo after metamorphosis, and most begin hematophagous feeding when they reach the estuary (Silva et al. 2013). This observation, together with the absence of postmetamorphic individuals in the river during the summer months (Cobo et al. 2010), and the limited time period during which it is possible to observe postmetamorphics in the River Ulla estuary (November-May), support the hypothesis that these individuals belong to the same cohort.

Mark-recapture studies of other anadromous populations throughout the geographic range might help to clarify this question.

Acknowledgements. The authors thank the staff of the Station of Hydrobiology of the USC 'Encoro do Con' for their participation in the surveys. We also thank the staff of Ximonde Permanent Trap for their collaboration in this study. This study has been partially supported by the project 10PXIB2111059PR of Xunta de Galicia and the project MIGRANET of the Interreg IV B SUDOE (southwest Europe) Territorial Cooperation Programme (SOE2/P2/E288). S.B. is supported by a grant from the PTA- MICINN (PTA20115566-I), Plan Nacional de I+D+i 2008-2011. 


\section{LITERATURE CITED}

Applegate VC (1950) Natural history of the sea lamprey (Petromyzon marinus) in Michigan. Spec Sci Rep 55, US Dept of Interior, Ann Arbor, MI

Barker LA, Morrison BJ, Wicks BJ, Beamish FWH (1997) Age discrimination and statolith diversity in sea lamprey from streams with varying alkalinity. Trans Am Fish Soc 126:1021-1026

Beamish FWH (1980) Biology of the North American anadromous sea lamprey, Petromyzon marinus. Can J Fish Aquat Sci 37:1924-1943

Beamish FWH, Medland TE (1988) Age determination for lampreys. Trans Am Fish Soc 117:63-71

$>$ Beamish FWH, Potter IC (1975) The biology of the anadromous sea lamprey (Petromyzon marinus) in New Brunswick. J Zool 177:57-72

Beaulaton L, Taverny C, Castelnaud G (2008) Fishing, abundance and life history traits of the anadromous sea lamprey (Petromyzon marinus) in Europe. Fish Res 92: 90-101

Bergstedt RA, Swink WD (1995) Seasonal growth and duration of the parasitic life stage of landlocked sea lampreys (Petromyzon marinus). Can J Fish Aquat Sci 52: 1257-1264

Caballero P, Cobo F, González MA (2006) Life history of a sea trout (Salmo trutta L.) population from the north-west Iberian Peninsula (River Ulla, Galicia, Spain). In: Harris G, Milner N (eds) Sea trout: biology, conservation and management. Blackwell, Oxford, p 234-247

Cobo F, Silva S, Vieira-Lanero R, Servia MJ and others (2010) Estado de conservación das poboacións de lamprea mariña en ríos de Galicia. Xunta de Galicia, Consellería do Medio Rural, Dirección Xeral de Conservation da Natureza, Santiago de Compostela

Farmer GJ (1980) Biology and physiology of feeding in adult lampreys. Can J Fish Aquat Sci 37:1751-1761

> Farmer GJ, Beamish FWH, Lett PF (1977) Influence of water temperature on the growth rate of the landlocked sea lamprey (Petromyzon marinus) and the associated rate of host mortality. J Fish Res Board Can 34:1373-1378

Griffiths RW, Beamish FWH, Morrison BJ, Barker LA (2001) Factors affecting larval sea lamprey growth and length at metamorphosis in lampricide-treated streams. Trans Am Fish Soc 130:289-306

Halliday RG (1991) Marine distribution of the sea lamprey (Petromyzon marinus) in the northwest Atlantic. Can J Fish Aquat Sci 48:832-842

Editorial responsibility: Thomas Turner, Albuquerque, New Mexico, USA
Hardisty MW (1979) Biology of the cyclostomes. Chapman \& Hall, London

Hardisty MW, Potter IC (1971) The general biology of adult lampreys. In: Hardisty MW, Potter IC (eds) The biology of lampreys, Vol 1. Academic Press, London, p 127-206

Johnson BGH, Anderson WC (1980) Predatory-phase sea lampreys (Petromyzon marinus) in the Great Lakes. Can J Fish Aquat Sci 37:2007-2020

> Morkert SB, Swink WD, Seelye JG (1998) Evidence for early metamorphosis of sea lampreys in the Chippewa River, Michigan. N Am J Fish Manage 18:966-971

OSPAR (2009) Background document for sea lamprey Petromyzon marinus. Biodiversity Series, OSPAR Commission, London

> Potter IC, Beamish FWH (1977) The freshwater biology of adult anadromous sea lampreys Petromyzon marinus. J Zool 181:113-130

Quintella BR, Andrade NO, Almeida PR (2003) Distribution, larval stage duration and growth of the sea lamprey ammocoetes, Petromyzon marinus L., in a highly modified river basin. Ecol Freshwat Fish 12:286-293

Quintella BR, Andrade NO, Koed A, Almeida PR (2004) Behavioural patterns of sea lampreys' spawning migration through difficult passage areas, studied by electromyogram telemetry. J Fish Biol 65:961-972

Quintella BR, Póvoa I, Almeida PR (2009) Swimming behaviour of upriver migrating sea lamprey assessed by electromyogram telemetry. J Appl Ichthyol 25:46-54

Ricker WE (1975) Computation and interpretation of biological statistics of fish population. Bull Fish Res Board Can 191:1-382

Ricker WE (1979) Growth rates and models. In: Hoar WS, Randall DJ, Brett JR (eds) Fish physiology. Bioenergetics and growth. Academic Press, New York, NY, p 677-743

Silva S, Servia MJ, Vieira-Lanero R, Cobo F (2013) Downstream migration and hematophagous feeding of newly metamorphosed sea lampreys (Petromyzon marinus Linnaeus, 1758). Hydrobiologia 700:277-286

Taverny C, Urdaci M, Elie AM, Beaulaton L, Ortusi I, Daverat F, Elie P (2005) Biologie, écologie et pêche des lamproies migratrices (Agnathes amphihalins): troisième tranche fonctionnelle. Rapport final. Etude Cemagref, Groupement de Bordeaux

Volk EC (1986) Use of calcareous otic elements (statoliths) to determine age of sea lamprey ammocoetes (Petromyzon marinus). Can J Fish Aquat Sci 43:718-722

Youson JH (1980) Morphology and physiology of lamprey metamorphosis. Can J Fish Aquat Sci 37:1687-1710

Submitted: May 29, 2012; Accepted: December 7, 2012

Proofs received from author(s): January 24, 2013 